\title{
Growth/Differentiation Factor-15/Macrophage Inhibitory Cytokine-1 Is a Novel Trophic Factor for Midbrain Dopaminergic Neurons In Vivo
}

\author{
Jens Strelau, ${ }^{1}$ Aideen Sullivan, ${ }^{2}$ Martina Böttner, ${ }^{1}$ Paul Lingor, ${ }^{1}$ Elisabeth Falkenstein, ${ }^{3}$ \\ Clemens Suter-Crazzolara, ${ }^{1}$ Dagmar Galter, ${ }^{1}$ Jozsef Jaszai, ${ }^{1}$ Kerstin Krieglstein, ${ }^{4}$ and Klaus Unsicker ${ }^{1}$ \\ 1Neuroanatomy and Interdisciplinary Center for Neurosciences, University of Heidelberg, D-69120 Heidelberg, Germany, \\ 2Department of Anatomy, University College, Cork, Ireland, ${ }^{3}$ Department of Clinical Pharmacology, Faculty for Clinical \\ Medicine, University of Heidelberg, D-68167 Mannheim, Germany, and ${ }^{4}$ Department of Anatomy, University of the \\ Saarland, D-66421 Homburg, Germany
}

Transforming growth factor- $\beta$ s (TGF- $\beta$ s) constitute an expanding family of multifunctional cytokines with prominent roles in development, cell proliferation, differentiation, and repair. We have cloned, expressed, and raised antibodies against a distant member of the TGF- $\beta$ s, growth/differentiation factor-15 (GDF-15). GDF-15 is identical to macrophage inhibitory cytokine-1 (MIC-1). GDF-15/MIC-1 mRNA and protein are widely distributed in the developing and adult CNS and peripheral nervous systems, including choroid plexus and CSF. GDF-15/MIC-1 is a potent survival promoting and protective factor for cultured and ironintoxicated dopaminergic (DAergic) neurons cultured from the embryonic rat midbrain floor. The trophic effect of GDF-15/MIC-1 was not accompanied by an increase in cell proliferation and astroglial maturation, suggesting that GDF-15/MIC-1 probably acts directly on neurons. GDF-15/MIC-1 also protects 6-hydroxydopamine (6-OHDA)-lesioned nigrostriatal DAergic neurons in vivo. Unilateral injections of GDF-15/MIC-1 into the medial forebrain bundle just above the substantia nigra (SN) and into the left ventricle (20 $\mu \mathrm{g}$ each) immediately before a 6-OHDA injection $(8 \mu \mathrm{g})$ prevented 6 -OHDA-induced rotational behavior and significantly reduced losses of DAergic neurons in the SN. This protection was evident for at least 1 month. Administration of $5 \mu \mathrm{g}$ of GDF-15/MIC-1 in the same paradigm also provided significant neuroprotection. GDF-15/MIC-1 also promoted the serotonergic phenotype of cultured raphe neurons but did not support survival of rat motoneurons. Thus, GDF-15/MIC-1 is a novel neurotrophic factor with prominent effects on DAergic and serotonergic neurons. GDF-15/MIC-1 may therefore have a potential for the treatment of Parkinson's disease and disorders of the serotonergic system.

Key words: GDF-15/MIC-1; TGF- $\beta$; dopaminergic neurons; 6-OHDA; Parkinson's disease; neurotrophic factor
Transforming growth factor- $\beta \mathrm{s}$ (TGF- $\beta \mathrm{s}$ ) are multifunctional, contextually acting cytokines and important regulators of development, cell proliferation, and differentiation (Roberts and Sporn, 1990). The TGF- $\beta$ superfamily can be subdivided into several subfamilies, including the bone morphogenetic proteins (BMPs), activins, and glial cell line-derived neurotrophic factor (GDNF)related proteins (Kingsley, 1994; Hogan, 1996; Unsicker et al., 1999). Several representatives of these subfamilies are expressed in the central and peripheral nervous systems (Krieglstein et al., 1995a; Mehler and Kessler, 1998). Their functions in neural development and maintenance are only gradually emerging. Several members of the TGF- $\beta$ s have been implicated in early morphogenesis of the nervous system, dorsoventral patterning, and determination of neural crest cell lineages (Hogan, 1996; Reissmann et al., 1996; Shah et al., 1996). Moreover, TGF- $\beta$ s are involved in regulating proliferation of neural progenitor cells (McKinnon et al., 1993; Constam et al., 1994). TGF- $\beta$ s have also important roles in the regulation of survival, differentiation, and axonal growth of neurons (Martinou et al., 1990; Ishihara et al., 1994; Krieglstein et al., 1998a; Schober et al., 1999) and orchestrate activities of microglial cells and astrocytes in response to lesions (Finch et al., 1993; Flanders et al., 1998). The neurotrophic potential of TGF- $\beta$ s is best exemplified by the discovery of GDNF (Lin et al., 1993; Sauer et al., 1995; Gash et

\footnotetext{
Received July 17, 2000; revised Sept. 5, 2000; accepted Sept. 11, 2000.

This work was supported by grants from Deutsche Forschungsgemeinschaft and Bundesministerium für Bildung und Forschung. We thank Jutta Fey, Anne Heinke, Marion Schmidt, and Ulla Hinz for excellent technical assistance.

Correspondence should be addressed to Klaus Unsicker, Neuroanatomy and Interdisciplinary Center for Neurosciences, University of Heidelberg, Im Neuenheime Feld 307, 2 OG, D-69120 Heidelberg, Germany. E-mail: klaus.unsicker@urz. uni-heidelberg.de.

Copyright (C) 2000 Society for Neuroscience $0270-6474 / 00 / 208597-07 \$ 15.00 / 0$
}

al., 1996; Unsicker et al., 1999), which supports survival and differentiation in vitro and in vivo of dopaminergic (DAergic) neurons of the midbrain that degenerate in Parkinson's disease.

We have recently cloned a distant member of the TGF- $\beta$ superfamily, GDF-15 (Böttner et al., 1998, 1999). GDF-15 is identical to macrophage inhibitory cytokine (Bootcov et al., 1997), hence, we suggest to name the molecule GDF-15/MIC-1. In peripheral organs GDF-15/MIC-1 is expressed by epithelial cells in prostate, salivary, and mammary glands, placenta, airway and intestinal epithelia, and kidney proximal tubules and collecting ducts (Böttner et al., 1999). Its functions in these locations are enigmatic. In macrophages, MIC-1 is induced by proinflammatory cytokines such as tumor necrosis factor- $\alpha$, interleukin (IL)- $1 \beta$, and IL-6, but not by interferon- $\gamma$ and lipopolysaccharide (Bootcov et al., 1997). Functionally, MIC-1 may serve in monocytoid cells as an autocrine regulatory molecule, whose expression may be required to limit later phases of macrophage activation.

We show now that GDF-15/MIC-1 is widely expressed in the CNS and peripheral nervous system (PNS), most prominently in the choroid plexus, and is secreted into the CSF. We have expressed the biologically active molecule in baculovirus and demonstrate here that it is a potent trophic and protective factor for dopaminergic neurons from the embryonic rat midbrain floor and for embryonic raphe serotonergic neurons. Most importantly, GDF-15/ MIC-1 normalizes motor behavior and protects dopaminergic neurons in the substantia nigra after unilateral 6-hydroxydopamine lesions, for at least 1 month.

\section{MATERIALS AND METHODS}

Expression of recombinant human GDF-15/MIC-1. Full-length GDF-15/ MIC-1 cDNA was cloned and sequenced as previously described (Böttner et al., 1998). A PCR product of the mature human GDF-15/MIC-1 DNA 
containing SacII/SphI restriction sites was obtained with two specific oligonucleotides (forward primer 5'-ATCCGCGGGCAGAGCGCGTGCGCGCAAC-3' and reverse primer 5'-ATCGTACGTCATATGCAGTGGCAG-3', internal SacII and SphI sites are underlined). The DNA fragment was subcloned into the SacII and SphI site of the pBACgus-2cp transfer plasmid (Novagen, Munich, Germany). To confirm the insert in the proper reading frame, we subsequently performed sequence analysis of the plasmid. Insect Sf9 cells were cotransfected with the recombinant transfer plasmid and the high-efficiency BacVector-2000 Triple Cut Virus DNA according to the manufacturer's instructions (Novagen, Munich, Germany). Together with the GDF-15/MIC-1 DNA a gus gene was inserted into the baculovirus genome, and recombinants producing $\beta$-glucuronidase in infected cells were identified by staining with X-Gluc. Positive recombinant virus plaques were picked and purified by repeated replaquing. A well isolated and purified plaque was used to generate a high titer master stock of virus $\left(3 \times 10^{9} \mathrm{pfu} / \mathrm{ml}\right)$, which was then used to prepare infected cells for protein and DNA analyses. Large scale protein production was performed in $10-2075 \mathrm{~cm}^{2}$ T-flasks each with $10 \mathrm{ml}$ of medium containing $10^{6}$ cells $/ \mathrm{ml}$. Sixty hour after infection cells were collected, centrifuged for $5 \mathrm{~min}$ at $500 \times \mathrm{g}$, and the pellet was homogenized in lysis buffer $\left(1 \mathrm{ml} / 1 \times 10^{8}\right.$ cells $)$ containing $10 \mathrm{mM}$ Tris $/ \mathrm{HCl}, \mathrm{pH}$ 7.5, $150 \mathrm{~mm} \mathrm{NaCl}, 0.1 \mathrm{U} / \mathrm{ml}$ aprotinin, and $1 \mathrm{mM} \mathrm{PMSF}$. After centrifugation for $10 \mathrm{~min}$ at $15,000 \times g$, the extracted protein was dialyzed against $1 \times$ binding buffer (in mM: 5 imidazole, $500 \mathrm{NaCl}$, and 20 Tris/ $\mathrm{HCl}, \mathrm{pH}$ 7.9). The His-Tag fusion protein was purified from protein extract using His-Bind metal chelation resin according to the protocol of Novagen (Munich, Germany). Protein extracts of uninfected cells were treated under the same conditions and used in parallel for controls.

In situ hybridization and RT-PCR. The procedure for in situ hybridization has been previously published (Böttner et al., 1999). RT-PCR was used to determine the expression pattern of GDF-15/MIC-1 in various brain regions and cell cultures of newborn (P0) Sprague Dawley rats. Protocols for dissection, cell culture, total RNA isolation, and first strand cDNA synthesis have been described elsewhere (Jaszai et al., 1998). After reverse transcription, $3.5 \mu \mathrm{l}$ of the cDNA samples were subjected to PCR amplification using primers specific for rat GDF-15/MIC-1 (5'-TGCTGAGCCGACTGCATGC-' 3 and 5'-CATGCTCAGTTGCAGCTGAC'3). These primers amplify a PCR product of $520 \mathrm{bp}$. Reactions were performed in a Perkin-Elmer GeneAmp PCR system 9600 thermal cycler in $0.2 \mathrm{ml}$ of thin-walled reaction tubes using "hot-start" method. Reagents were assembled in a final volume of $100 \mu \mathrm{l}$, and final concentrations of reagents were as follows: $3.5 \mu \mathrm{l}$ of first strand cDNA, $1 \mu \mathrm{M}$ forward primer, $1 \mu \mathrm{M}$ reverse primer, $1 \times$ PCR buffer $(10 \times$ PCR buffer: $200 \mathrm{~mm}$ Tris-HCl, pH 8.4, 500 mM KCl; Life Technologies, Gaithersburg, MD), $2.5 \mathrm{mM} \mathrm{MgCl}_{2}, 0.1$ $\mathrm{mm}$ each of dNTPs and RNase-free water to $100 \mu \mathrm{l}$. Samples were initially denatured at $94^{\circ} \mathrm{C}$ for $4 \mathrm{~min}$ and $2.5 \mathrm{U}$ of Taq DNA polymerase, recombinant (Life Technologies) was then added. Thermocycling parameters were then 30 sec denaturation at $94^{\circ} \mathrm{C}, 30 \mathrm{sec}$ annealing at $62^{\circ} \mathrm{C}$, and $30 \mathrm{sec}$ extension at $72^{\circ} \mathrm{C}$ repeated for 35 cycles with a final extension step at $72^{\circ} \mathrm{C}$ for $5 \mathrm{~min}$. One-tenth of each PCR reaction was then analyzed by agarose gel electrophoresis. After subcloning the reaction product into pGEM-T (Promega, Mannheim, Germany) PCR cloning vector, the identity of the amplified product was then further verified by sequencing.

Gel electrophoresis and immunoblot analysis. Protein extracts were prepared from different brain regions and cell cultures of newborn (P0) Sprague Dawley rats. Protocols for dissection and cell cultures have been described elsewhere (Jaszai et al., 1998). Tissue or cells were homogenized in electrophoresis sample buffer, and the protein content was determined using a densitometric method (Henkel and Bieger, 1994). Equal amounts of $25 \mu \mathrm{g}$ of protein extract per lane were loaded on SDS-polyacrylamide gels and transferred to nitrocellulose membranes (Hybond ECL; Amersham Pharmacia, Göttingen, Germany) by electroblotting. The membranes were incubated with purified polyclonal rabbit anti-rat GDF-15/MIC-1 antibody for $16 \mathrm{hr}$ at $4^{\circ} \mathrm{C}$. Bound antibody was detected with a peroxidaseconjugated secondary antibody and the ECL Western blotting substrate system (Amersham Pharmacia, Göttingen, Germany) in accordance to the manufacturer's manual. Purified recombinant GDF-15/MIC-1 samples were visualized with Coomassie blue and quantitated by densitometric comparison (Henkel and Bieger, 1994) with defined concentrations of protein standards. Recombinant GDF-15/MIC-1 was analyzed by reducing and nonreducing SDS-PAGE according to standard protocols (Scopes, 1987) and subjected to immunoblotting. Human CSF was kindly provided by Dr. Grau (Neurology, Heidelberg University).

Antibodies and immunocytochemistry. An antibody raised against a specific peptide sequence (HRTDSGVSLQTYDDL) of the C terminus of the GDF-15/MIC-1 protein was raised in rabbit by Dr. J. Pineda (Forschungszentrum Berlin Biotechnik, GmbH, Berlin, Germany). The antibody was separated from antiserum with tosylactivated peptide-coated dynabeads M-280 (Dynal, Hamburg, Germany) according to the manufacturer's manual. In brief, $1 \mathrm{ml}$ of bead suspension $\left(1.3 \times 10^{9}\right.$ beads $\left./ \mathrm{ml}\right)$ was incubated

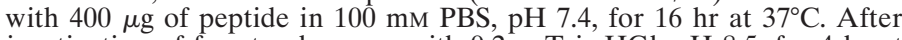
inactivation of free tosyl groups with $0.2 \mathrm{M}$ Tris-HCl, $\mathrm{pH} 8.5$, for $4 \mathrm{hr}$ at $37^{\circ} \mathrm{C}$ the peptide-coupled beads were incubated with $0.5 \mathrm{ml}$ of antiserum in $1 \mathrm{ml}$ of PBS for $30 \mathrm{~min}$ at room temperature. After intensive washing and immunomagnetic separation in a magnet particle concentrator (Dynal) bound antibody was eluted from the peptide-coupled beads with $0.3 \mathrm{ml}$ of elution buffer containing $0.2 \mathrm{M}$ glycine- $\mathrm{HCl}, \mathrm{pH} 2.7$, and $0.15 \mathrm{M} \mathrm{NaCl}$ for
$1 \mathrm{~min}$ at room temperature. The solution with unbound antibody was carefully aspirated with an Eppendorf pipette and neutralized immediately with $0.1 \mathrm{ml}$ of $0.4 \mathrm{M} \mathrm{Na}_{2} \mathrm{HPO}_{4}$ containing $0.8 \% \mathrm{Na}$-azide and $4 \mathrm{mg} / \mathrm{ml}$ BSA. The antibody was stored in a final volume of $0.4 \mathrm{ml}$ at $4^{\circ} \mathrm{C}$ and used in a 1:250 dilution for Western blots. Mesencephalic cell cultures were processed for rat tyrosine hydroxylase (TH; Boehringer Mannheim, Mannheim, Germany), glial fibrillary acidic protein (GFAP; Sigma, St. Louis, MO) or BrdU (Boehringer Mannheim) immunocytochemistry as described earlier (Krieglstein et al., 1995b). Serotonergic cultures were processed for rat tryptophan hydroxylase (TpOH; Sigma) immunocytochemistry. The method was as described (Galter and Unsicker, 1999).

Cell culture. Cell cultures from embryonic day 14 (E14) rat midbrain floor were essentially established as described (Krieglstein et al., 1995b). Cells were seeded at a density of 200,000 per $\mathrm{cm}^{2}$, cultured under serumfree conditions, and processed for immunocytochemistry on day 7 in vitro (DIV 7). Iron intoxication was performed with $\mathrm{FeCl}_{2}$ (Fluka, Deisenhofen, Germany) as described (Lingor et al., 1999). Primary raphe cultures from the E14 rat rhombencephalon floor were prepared as described (Galter and Unsicker, 1999). Cells were seeded at a density of 200,000 per $\mathrm{cm}^{2}$, cultured under serum-free conditions and processed for 5,7dihydroxtryptamine (5,7-DHT) uptake and $\mathrm{TpOH}$ immunocytochemistry on DIV 4. Embryonic rat motoneurons (E14) were prepared as described (Goudin et al., 1996; Krieglstein et al., 1998a), using a two-step purification method [metrizamide gradient followed by a panning procedure using the monoclonal antibody MC-192 that recognizes the low-affinity nerve growth factor (NGF) receptor]. Embryonic chick (E8) dorsal root ganglia (DRG) neurons were isolated and grown as described (Krieglstein et al., 1998a). Type 2 astrocytes, O-2A progenitor cells, and oligodendrocytes were obtained from primary cortical glial cultures established from $\mathrm{P} 0$ rats, as previously described (Behar et al., 1988). The oligodendroglial progenitor cell line OLI-neu (Jung et al., 1995) was kindly provided by Dr. J. Trotter (Neurobiology, Heidelberg University, Germany). Growth factors were from Immunocytochemicals (Ismaning, Germany) (NT-4, GDNF, both human recombinant) and Boehringer Mannheim (NGF, 2.5 S).

In vivo studies. Adult female Wistar rats (240-260 $\mathrm{gm})$ were anesthetized using ketamine (75 mg/kg, i.p.) and xylazinum $(15 \mathrm{mg} / \mathrm{kg}$, i.p.) and placed in a Kopf stereotaxic frame. GDF-15/MIC-1 was used at a final concentration of $2 \mu \mathrm{g} / \mu \mathrm{l}$ in $10 \mathrm{mM}$ PBS, $\mathrm{pH}$ 7.4. Ten rats received injections of $20 \mu \mathrm{g}$ of GDF-15/M IC-1 just above the left substantia nigra (SN) plus $20 \mu \mathrm{g}$ GDF-15/MIC-1 into the left lateral ventricle (LV), whereas five additional rats received injections of $5 \mu \mathrm{g}$ of GDF-15/M IC-1 into each of the same sites. This was followed immediately by an injection of 6-hydroxydopamine (6-OHDA) hydrobromide $(8 \mu \mathrm{g}$ as the free base in $4 \mu \mathrm{l}$ of $0.9 \%$ saline with $0.1 \%$ ascorbic acid) into the left medial forebrain bundle (MFB) of each rat. Ten further rats received sham injections of 10 $\mathrm{mM}$ PBS into the SN and LV, in addition to a 6-OHDA injection ("6OHDA only" group). Stereotaxic coordinates (Pellegrino et al., 1979) were as follows: anteroposterior (AP) $-3.0, \mathrm{LV}+2.5$, dorsoventral (DV) -8.5 for the SN; $\mathrm{AP}+1.0, \mathrm{LV}+1.2, \mathrm{DV}-3.5$ for the $\mathrm{LV}$; $\mathrm{AP}-2.2, \mathrm{LV}+1.5$, DV -7.9 for the MFB.

All rats were tested behaviorally at 1 week after surgery, and the 1 month group of rats was tested again after a further 1 and 2 weeks. Ipsilateral rotations were counted over a $60 \mathrm{~min}$ period beginning $5 \mathrm{~min}$ after $(+)$-amphetamine sulfate administration $(5 \mathrm{mg} / \mathrm{kg}$, i.p. $)$.

At $10 \mathrm{~d}$ after surgery, five rats of the 6-OHDA only group, five rats that had received a total dose of $40 \mu \mathrm{g}$ of GDF-15/M IC-1, and five rats that had received a total dose of $10 \mu \mathrm{g}$ of GDF-15/M IC-1 were killed. They were terminally anesthetized with chloroform/ether and perfused intracardially with $200 \mathrm{ml}$ of cold $0.1 \mathrm{M}$ PBS, pH 7.4, containing $500 \mathrm{U}$ of heparin, followed by $300 \mathrm{ml}$ of freshly prepared $4 \%$ paraformaldehyde in PBS. The remaining five rats of the $40 \mu \mathrm{g}$ group and five of the 6-OHDA only group were killed at 1 month after surgery. Five unlesioned control rats were also killed at this time. Brains were removed and placed in $4 \%$ paraformaldehyde in $10 \mathrm{~mm}$ PBS overnight, cryoprotected in $30 \%$ sucrose in PBS, and then frozen. Serial $30 \mu \mathrm{m}$ coronal cryosections through the SN pars compacta $(\mathrm{SNpc})$ were cut and stained immunocytochemically for $\mathrm{TH}$. Sections were incubated in blocking solution (3\% normal goat serum, $0.2 \%$ Triton X-100 in PBS) overnight at $4^{\circ} \mathrm{C}$, then in a 1:200 solution of mouse antibody to $\mathrm{TH}$ (Boehringer Mannheim) in blocking solution overnight at $4^{\circ} \mathrm{C}$. Sections were washed five times in PBS containing $0.02 \%$ Triton $\mathrm{X}-100$, then incubated in a solution of 1:1000 horseradish peroxidaselinked anti-rabbit IgG (Vector Laboratories, Peterborough, UK) overnight at $4^{\circ} \mathrm{C}$. After washing as before, TH immunostaining was visualized using $3,3^{\prime}$-diaminobenzidine as the chromogen. Sections were mounted onto gelatinized slides, dehydrated in alcohol, cleared in xylene, and mounted in DePeX.

Unbiased stereological analysis of TH-immunopositive neurons in the left and right $\mathrm{SN}$ of each brain was performed using a drawing tube attachment on an Olympus BX40 light microscope. The volume of each SN was estimated using the Cavalieri method, which was applied to six cryosections per brain (with an intersection distance of $200 \mu \mathrm{m}$ ). The number of TH-immunopositive neurons per unit volume was estimated using the Disector method, on three Disector pairs per brain (pilot studies suggested that three pairs were sufficient for such an estimate). These estimates were used to calculate the absolute numbers of $\mathrm{TH}$ immunopositive neurons per left or right SN. ANOVA analysis with post 
A

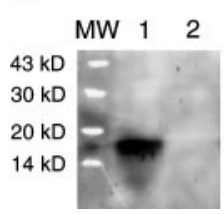

B

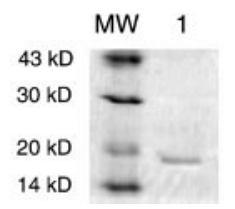

C

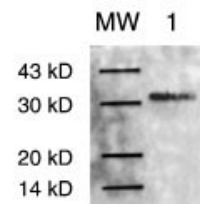

\section{RESULTS}

\section{Cloning, expression, and distribution of GDF-15/MIC-1 in the nervous system}

Members of the TGF- $\beta$ superfamily share a distinct spacing of seven conserved cysteine residues within the mature $\mathrm{C}$-terminal portion that form a characteristic cysteine knot motif (McDonald and Hendrickson, 1993). Using this motif for screening expressed sequence tag (EST) databases resulted in the identification of several identical truncated sequences with the characteristic TGF- $\beta$ structure. RT-PCR combined with cDNA library screening revealed the full-length human, mouse, and rat sequences of a novel member of the TGF- $\beta$ superfamily (Böttner et al., 1998, 1999). We used a His-Tag fusion construct and a baculovirus system for expressing the mature portion of recombinant human GDF-15/ MIC-1 protein in Sf9 cells (Fig. $1 A-C$ ) and raised antibodies against a $\mathrm{C}$-terminal synthetic peptide. To demonstrate the specificity of the antibodies, immunoblot analyses with other TGF- $\beta$ superfamily members were performed. The GDF-15/MIC-1 antibodies revealed no cross-reactivity with members of the TGF- $\beta$, BMP, or GDNF subfamilies (data not shown). Western blots under reducing conditions showed that recombinant GDF-15/MIC-1 migrates at $\sim 16 \mathrm{kDa}$ (Fig. $1 A$ ), i.e., close to the size of the mature peptide of $12.5 \mathrm{kDa}$ (Bootcov et al., 1997). The difference in the observed bands is probably because of the presence of the His-Tag in the recombinant protein. Under nonreducing conditions, the expression product migrates as a disulfide-linked dimer (Fig. 1C). We used these antibodies, RT-PCR, and in situ hybridization to reveal regions of expression of GDF-15/MIC-1 in the developing and adult brain, in isolated neural cells and peripheral neural tissues (Fig. 2). GDF-15/MIC-1 mRNA and protein can be detected in many brain areas, including cortex, hippocampus, striatum, pons, and medulla oblongata (Fig. $2 C, D$ ). In situ hybridization revealed the choroid plexus as a prominent site of synthesis in the CNS (Fig. 2B). Consistent with this localization of GDF-15/ MIC-1 mRNA the protein can be detected by immunocytochemistry in the plexus epithelium (data not shown) and by Western blot in the CSF (Fig. 2A). Expression levels of GDF-15/MIC-1 mRNA and protein in brain areas other than the choroid plexus were too low to be detected by in situ hybridization and immunocytochemistry, respectively. However, cortical lesions can raise GDF-15/ MIC-1 mRNA in select neuron populations to levels sufficient for visualization by in situ hybridization (M. Böttner, unpublished observations). GDF-15/MIC-1 expression is not restricted to the $\mathrm{CNS}$, as shown by the presence of mRNA and protein in DRG (Fig. 2C,D). RT-PCR and Western blot studies using isolated neural cells revealed the presence of GDF-15/MIC-1 in highly enriched cultured astrocytes, but not in purified O-2A oligodendroglial progenitor cells and an oligodendroglial cell line, OLI-neu
A

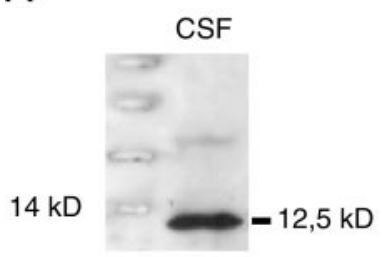

C

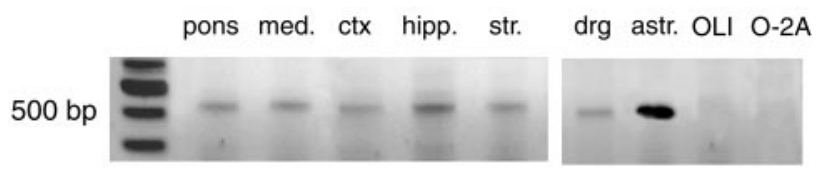

D

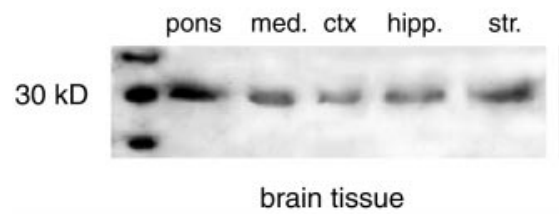

Western blot

B

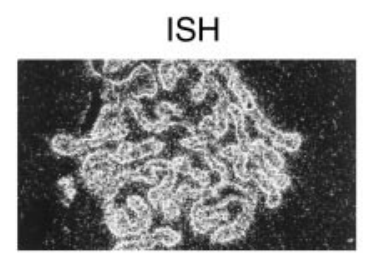

\section{RT-PCR} Figure 2. Localization of GDF-15/MIC-1 in the CNS. $A$, Immunoblotting
of human CSF with purified GDF-15/MIC-1 antiserum. B, Dark-field image shows in situ hybridization of adult rat choroid plexus with a ratspecific GDF-15/MIC-1 antisense RNA probe. $C$, RT-PCR of different rat (P0) brain regions (pons, medulla oblongata, cortex, hippocampus, striatum), dorsal root ganglia ( $d r g$ ), cultured primary astrocytes (astr.), the oligodendroglial cell line OLI-neu $(O L I)$, and purified oligodendroglial progenitor cells $(O-2 A)$. D, Immunoblotting of rat brain tissues (P0) and cells with purified GDF-15/MIC-1 antiserum. Locations of molecular weight marker bands are provided on the left side of each figure.

(Fig. 2C,D). Together, these data suggest that GDF-15/MIC-1 is widely distributed in the CNS and in the CSF.

\section{GDF-15/MIC-1 promotes survival of cultured and iron- intoxicated midbrain dopaminergic neurons}

We next assayed the recombinant purified protein from Sf 9 cells on a variety of cultured CNS and PNS neurons for biological activity and putative neurotrophic effects. As shown in Figure $3 A-C$, GDF-15/MIC-1 is a potent trophic factor for DAergic neurons cultured from the E14 rat midbrain floor. The factor increases DAergic neuron survival at an optimal concentration (estimated $1 \mathrm{ng} / \mathrm{ml}$ ), twofold above control levels (Fig. 4A). Thus, GDF-15/M IC-1 is at least as potent as the best-established dopaminotrophic factor GDNF (Figs. $3 A-C, 4 A$ ). Figure $3 D-F$ documents that GDF-15/MIC-1 did not increase the number of cells immunoreactive for the astroglial intermediate filament protein GFAP. Moreover, GDF-15/MIC-1 did not increase numbers of BrdUincorporating cells (data not shown). This suggests that GDF-15/ MIC-1 probably acts directly on neurons and not through a numerical expansion of cells or stimulation of astroglial cell maturation.

Toxins and free radical formation have been implicated in the generation of cell losses in Parkinson's disease (Gerlach and Riederer, 1996). We therefore investigated whether GDF-15/MIC-1 was able to protect iron-intoxicated cultured midbrain DAergic neurons from cell death. Figure $4 B$ documents that GDF-15/ MIC-1 (10 ng/ml) significantly protects DAergic neurons against iron intoxication matching the effect of NT-4 $(10 \mathrm{ng} / \mathrm{ml})$, an established neuroprotective factor for lesioned DAergic neurons (Lingor et al., 1999). Together, these data indicate that GDF-15/MIC-1 is both a trophic and neuroprotective factor for midbrain DAergic neurons in vitro. 
TH
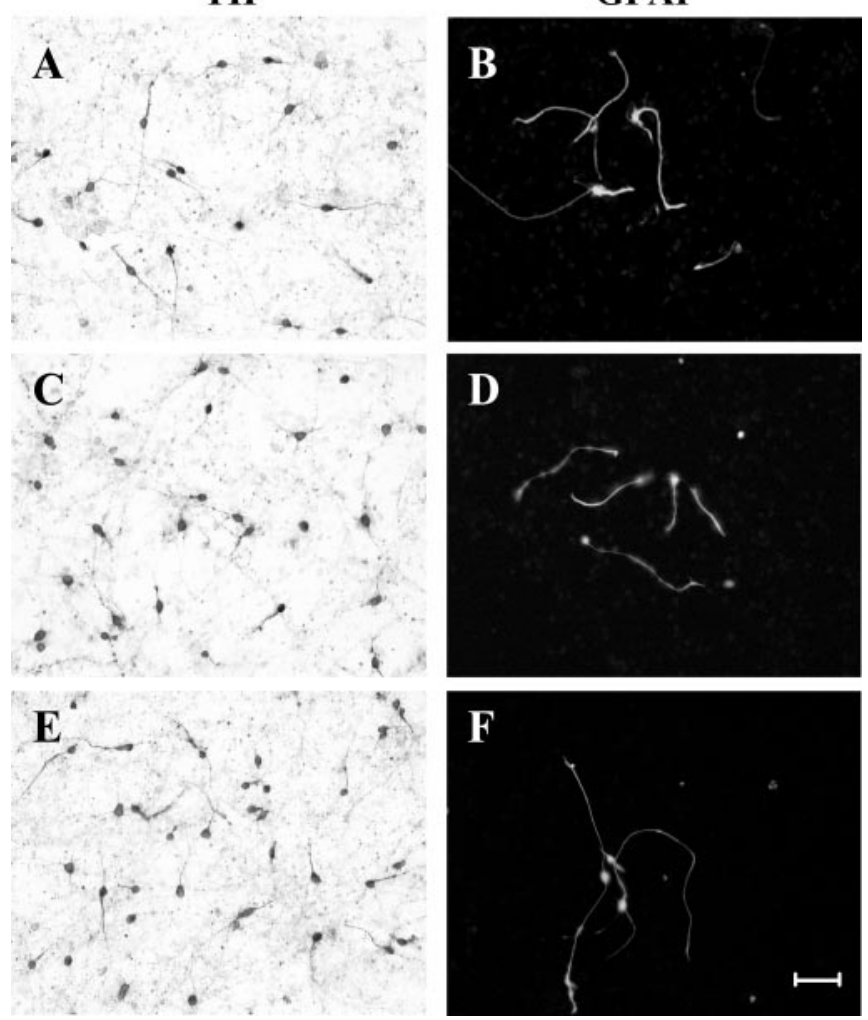
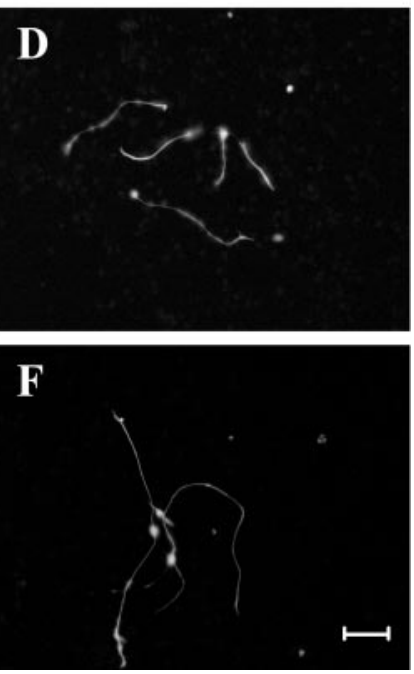

Figure 3. Photomicrographs of cell cultures established from the E14 rat midbrain floor at DIV 7. Panels show staining with monoclonal antibodies against TH $(A, C, E)$ or GFAP $(B, D, F)$, respectively. Cultures were run as controls $(A, B)$, or treated with GDNF $(10 \mathrm{ng} / \mathrm{ml} ; C, D)$, or GDF-15/M MC-1 $(1 \mathrm{ng} / \mathrm{ml} ; E, F)$. Scale bar, $50 \mu \mathrm{m}$.

\section{GDF-15/MIC-1 promotes the serotonergic phenotype of raphe neurons, but does not affect spinal motoneurons}

We also assayed GDF-15/MIC-1 on several other CNS and peripheral neuron populations. Figure $4 C$ shows that GDF-15/MIC-1 augmented numbers of neurons immunoreactive for the 5-HTsynthesizing enzyme $\mathrm{TpOH}$ and cells taking up the serotonin analog 5,7-dihydroxytryptamine (5,7-DHT) in cultures established from the E14 rat raphe. GDF-15/MIC-1 did not promote the survival of purified rat spinal cord motoneurons in vitro (data not shown), but had a small, yet significant promoting effect on chick DRG neurons (Fig. 4D).

\section{GDF-15/MIC-1 protects 6-hydroxydopamine-lesioned nigrostriatal neurons in vivo}

The neuroprotective effects of GDF-15/MIC-1 were examined in vivo in adult rats that had received unilateral 6-OHDA-induced lesions of the nigrostriatal pathway. GDF-15/MIC-1 was administered just above the $\mathrm{SN}$ and into the $\mathrm{LV}$, a protocol described previously for measuring the effects of GDF-5 and GDNF in this rat model (Sullivan et al., 1997, 1998).

A total dose of $40 \mu \mathrm{g}$ of GDF-15/MIC-1 completely prevented 6-OHDA-induced rotational asymmetry, indicating that it protected against 6-OHDA-induced depletion of striatal dopamine levels (Table 1). This protective effect on rotational behavior was observed for up to 3 weeks after the lesion. A total dose of $10 \mu \mathrm{g}$ of GDF-15/MIC-1 also induced significant protection $(p>0.0001)$ against amphetamine-induced rotations at 1 week after the lesion.

GDF-15/MIC-1 also exhibited potent protective effects on dopaminergic neurons in the SNpc (Table 1, Fig. 5). Both of the 6-OHDA only groups exhibited a large loss of TH-immunopositive neurons in the left SNpc (neurons on left expressed as a percentage of those on right: $6.1 \pm 2.0 \%$ at $10 \mathrm{~d}$ and $5.8 \pm 1.3 \%$ at 1 month). Both doses of GDF-15/MIC-1 significantly ( $p<0.001$ for $10 \mu \mathrm{g}$;
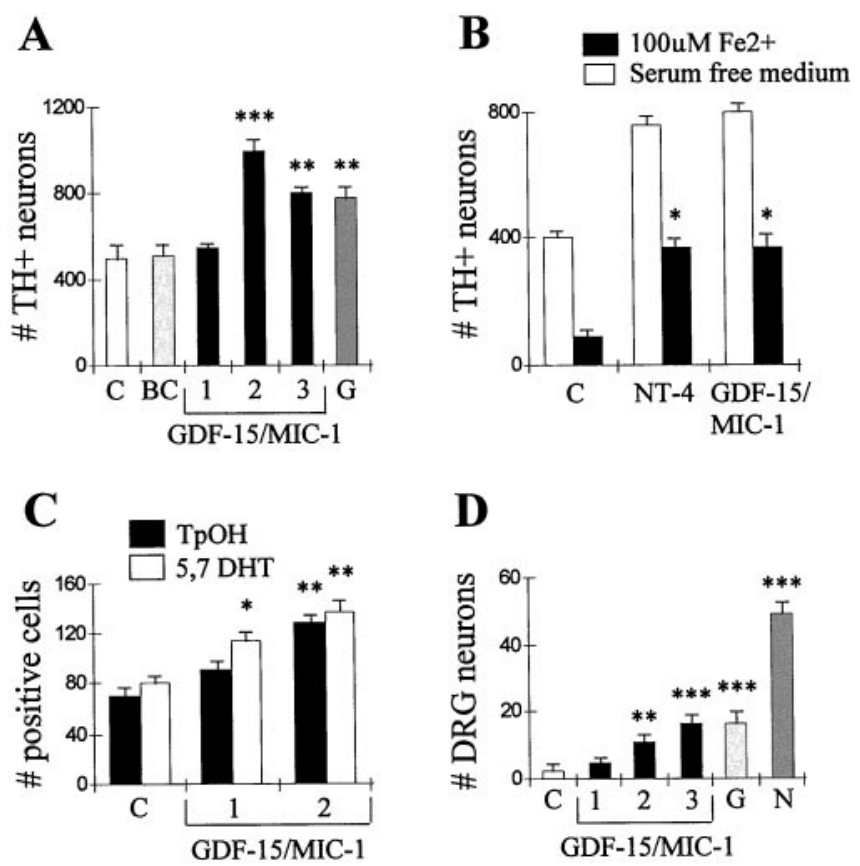

Figure 4. In vitro neurotrophic effects of GDF-15/M IC-1. GDF-15/M IC-1 was assayed on rat midbrain DAergic neurons $(A, B)$, rat serotonergic raphe neurons $(C)$, and chick DRG neurons $(D)$. $A$, Numbers of mesencephalic TH-positive neurons at DIV 7. $C$, No factors; $B C$, baculovirus control, i.e. noninfected cells; $1,2,3$, cultures treated with $0.01,0.1$, and $1 \mathrm{ng} / \mathrm{ml}$ GDF-15/MIC-1, respectively; $G$, GDNF (10 ng/ml). $B$, Numbers of mesencephalic TH-positive neurons at DIV 8, after intoxication with $100 \mu \mathrm{M} \mathrm{Fe}{ }^{2+}$ $C$, No factors; NT-4 (10 ng/ml); GDF-15/M IC-1 $(1 \mathrm{ng} / \mathrm{ml})$. $C$, Numbers of TpOH and 5,7 DHT-positive cells at DIV 4 in cultures established from rat E14 raphe. $C$, Control; 1,2, Cultures treated with 5 (1) or $10 \mathrm{ng} / \mathrm{ml}$ (2) GDF-15/MIC-1. D, Numbers of chick (E8) DRG neurons at DIV 2. $C$, Control, 1, 2, 3, cultures treated with 1,5 , or $10 \mathrm{ng} / \mathrm{ml}$ GDF-15/MIC-1; $G$, cultures treated with GDNF $(10 \mathrm{ng} / \mathrm{ml}) ; N$, cultures treated with NGF $(10$ $\mathrm{ng} / \mathrm{ml})$. Data are given as means $\pm \operatorname{SEM}(n=3)$. All experiments were performed in triplicate and repeated at least three times. $p$ values derived from Student's $t$ test are ${ }^{*} p<0.05,{ }^{*} p<0.01,{ }^{* * *} p<0.001$.

$p<0.0001$ for $40 \mu \mathrm{g}$ ) prevented this 6-OHDA-induced loss of dopaminergic neurons in the left SNpc (survival of $51.1 \pm 4.0 \%$ after $10 \mu \mathrm{g} ; 67.7 \pm 3.6 \%$ after $40 \mu \mathrm{g}$ ). Furthermore, this significant sparing of TH-positive neurons was still evident after 1 month in rats treated with $40 \mu \mathrm{g}$ of GDF-15/MIC-1 $(62.0 \pm 3.4 \% ; p<0.001)$. The sparing induced by $40 \mu \mathrm{g}$ of GDF-15/MIC-1 after 1 month was not significantly different from that seen after 1 week, showing that the protein induced long-term neuroprotective effects.

\section{DISCUSSION}

The present data reveal the neurotrophic and neuroprotective potential of a new member of the TGF- $\beta$ superfamily in vitro and in vivo. TGF- $\beta$ s share a primary structure with six $\mathrm{C}$-terminal cysteines in topologically equivalent positions that form a cysteine knot motif. This structural information was used in an EST database search and resulted in the identification and cloning of the full-length coding sequence of GDF-15 (Böttner et al., 1998, 1999). GDF-15 is identical to MIC-1 (Bootcov et al., 1997), which was discovered independently, based on its capacity to inhibit lipopolysaccharide-induced macrophage activation. Amino acid identity with other members of the TGF- $\beta$ superfamily is $32 \%$ and less (Böttner et al., 1999). GDF-15/MIC-1 does not mimic TGF- $\beta$ isoforms 1 , 2, and 3 in an assay of mink lung epithelial cells (K. Krieglstein and J. Strelau, unpublished observations), suggesting that GDF-15/MIC-1 may not use the TGF- $\beta$ type I and II receptors (Lin et al., 1992).

As shown by RT-PCR and in situ hybridization, GDF-15/MIC-1 mRNA is widely distributed in peripheral organs of rat and mouse including the gastrointestinal and respiratory tracts, salivary, mammary, and prostate glands, placenta, kidney, and adrenal glands (Böttner et al., 1999). In situ hybridization shows prominent ex- 
Table 1. Rotations per minute after amphetamine administration and counts of TH-immunopositive neurons in left and right SNpc

\begin{tabular}{|c|c|c|c|c|c|c|c|}
\hline \multirow[b]{2}{*}{ Treatment } & \multicolumn{3}{|c|}{ Rotations per minute } & \multicolumn{4}{|c|}{ Total TH-positive neuron counts in SNpc $(\times 100)$} \\
\hline & 1 week & 2 weeks & 3 weeks & Left $(\mathrm{L})$ & Right (R) & $\mathrm{L} / \mathrm{R}(\%)($ mean & $\pm \mathrm{SD})$ \\
\hline \multirow[t]{5}{*}{ 6-OHDA only (10 d) } & 13 & & & & $8.3 \pm 2.5$ & $113.6 \pm 9.6$ & \\
\hline & 11 & & & $10.8 \pm 1.1$ & $115.2 \pm 1.8$ & & \\
\hline & 9 & & & $5.5 \pm 2.1$ & $113.7 \pm 3.8$ & & \\
\hline & 11 & & & $5.3 \pm 1.9$ & $107.2 \pm 4.2$ & & \\
\hline & 14 & & & $4.7 \pm 1.2$ & $116.3 \pm 5.1$ & $6.1 \pm 2.0(n=$ & 5) \\
\hline \multirow[t]{5}{*}{ GDF-15-10 $\mu \mathrm{g}(10 \mathrm{~d})$} & 3 & & & $63.2 \pm 8.2$ & $114.5 \pm 2.2$ & & \\
\hline & 4 & & & $57.8 \pm 3.5$ & $105.8 \pm 3.6$ & & \\
\hline & 5 & & & $55.6 \pm 2.7$ & $110.2 \pm 6.9$ & & \\
\hline & 2 & & & $60.8 \pm 5.6$ & $118.6 \pm 2.9$ & & \\
\hline & 6 & & & $50.2 \pm 9.1$ & $114.4 \pm 4.8$ & $51.1 \pm 4.0(n=$ & 5) \\
\hline \multirow[t]{5}{*}{ GDF-15-40 $\mu \mathrm{g}(10 \mathrm{~d})$} & 0 & & & $74.5 \pm 3.9$ & $111.7 \pm 2.8$ & & \\
\hline & 1 & & & $73.1 \pm 2.8$ & $113.6 \pm 2.4$ & & \\
\hline & 2 & & & $90.2 \pm 6.1$ & $125.3 \pm 2.9$ & & \\
\hline & 0 & & & $86.1 \pm 5.0$ & $119.8 \pm 2.5$ & & \\
\hline & 0 & & & $69.3 \pm 5.1$ & $108.7 \pm 3.9$ & $67.7 \pm 3.6(n=$ & 5) \\
\hline \multirow[t]{5}{*}{ 6-OHDA only (1 month) } & 11 & 13 & 14 & $5.6 \pm 2.3$ & $99.5 \pm 10.2$ & & \\
\hline & 9 & 10 & 15 & $9.4 \pm 3.8$ & $115.6 \pm 3.8$ & & \\
\hline & 16 & 16 & 20 & $6.5 \pm 2.2$ & $114.5 \pm 5.8$ & & \\
\hline & 14 & 16 & 21 & $4.7 \pm 3.9$ & $120.3 \pm 6.3$ & & \\
\hline & 10 & 14 & 18 & $6.6 \pm 3.6$ & $119.8 \pm 7.2$ & $5.8 \pm 1.3(n=$ & 5) \\
\hline \multirow[t]{5}{*}{ GDF-15-40 $\mu \mathrm{g}$ (1 month) } & 0 & 0 & 0 & $70.8 \pm 5.5$ & $122.0 \pm 5.7$ & & \\
\hline & 0 & 0 & 0 & $71.2 \pm 6.6$ & $114.5 \pm 3.6$ & & \\
\hline & 1 & 0 & 0 & $77.8 \pm 2.5$ & $119.8 \pm 5.4$ & & \\
\hline & 1 & 1 & 0 & $80.1 \pm 5.5$ & $120.5 \pm 6.3$ & & \\
\hline & 0 & 0 & 0 & $69.5 \pm 1.8$ & $118.5 \pm 6.4$ & $62.0 \pm 3.4(n=$ & 5) \\
\hline \multirow[t]{5}{*}{ Unlesioned } & 0 & 0 & 0 & $119.8 \pm 3.4$ & $117.6 \pm 9.8$ & & \\
\hline & 0 & 0 & 0 & $102.2 \pm 8.2$ & $100.9 \pm 3.2$ & & \\
\hline & 0 & 0 & 0 & $120.3 \pm 3.6$ & $129.0 \pm 2.3$ & & \\
\hline & 0 & 0 & 0 & $114.4 \pm 10.2$ & $112.9 \pm 8.4$ & & \\
\hline & 0 & 0 & 0 & $123.3 \pm 9.1$ & $110.2 \pm 4.0$ & $101.9 \pm 5.9(n=$ & $5)$ \\
\hline
\end{tabular}

pression of GDF-15/MIC-1 mRNA in epithelial cells and macrophages, but not in mesenchyme-derived cells. The present study reveals GDF-15/MIC-1 synthesis in the choroid plexus and its secretion into CSF, from where a wide range of signaling proteins may reach target cells within the brain and spinal cord (Dixon et al., 1997). Many other cytokines with neurotrophic functions, as e.g., fibroblast growth factors-1 and -2 (for review, see Bieger and Unsicker, 1996), insulin-like growth factors I and II (for review, see Cohick and Clemmons, 1993), and TGF- $\beta$ s (for review, see Böttner et al., 2000) show a similarly wide distribution in many peripheral tissues and in the brain, but are broader than GDF-15/M IC-1 with regard to the spectrum of neuron populations supported (see below). Not only endogenous, but also exogenously administered molecules, such as neurotrophic factors applied as therapeutic agents against several neurodegenerative diseases, can be distributed within the brain by intraventricular and intrathecal routes (Aebischer et al., 1996). RT-PCR and Western blot analyses suggest that GDF-15/MIC-1 is also synthesized and stored in CNS tissues other than choroid plexus, as e.g., cortex, hippocampus, striatum, pons, and medulla oblongata. However, mRNA and protein levels in these locations are apparently too low to be visualized by in situ hybridization and immunocytochemistry. Western blots of brain homogenates and lysates of cultured cells reveal one immunoreactive band migrating at $\sim 30 \mathrm{kDa}$. This corresponds to the calculated size of the pro-protein. Because the antibodies used also recognize the mature form of GDF-15/MIC-1, as demonstrated with the recombinant (Fig. $1 A$; calculated MW $\sim 14.5 \mathrm{kDa}$ ) and CSF-derived protein (Fig. $2 A ; \sim 12.5$ ), we assume that levels of mature GDF-15/MIC-1 in tissue and cell lysates may be below detection limit. This assumption is supported by the previous demonstration that intracellular MIC-1 exists predominantly in its pro-form (Bootcov et al., 1997).

Synthesis of GDF-15/MIC-1 by choroid plexus epithelial cells is reminiscent of TGF- $\beta 1$, which is also strongly expressed in the choroid plexus, but hardly detectable in brain parenchyma (Flanders et al., 1989). Like GDF-15/MIC-1, TGF- $\beta 1$ is secreted into the CSF (Huang et al., 1997) and acts as a trophic factor on several classes of CNS neurons (Krieglstein et al., 1995a).

The capacity of GDF-15/MIC-1 to promote survival and phenotypical development of mesencephalic DAergic and raphe serotonergic neurons denotes the first known functions of this molecule in the nervous system. The neurotrophic effects were seen on both unlesioned and toxically impaired DAergic neurons both in vitro and in vivo. A growing body of evidence suggests that increased formation of toxic radicals as well as decreased radical scavenger activities (Ruberg et al., 1997) may play major roles in neuronal death. Iron catalyzes, by means of the fenton reaction, the production of the $\mathrm{HO}$ radical from hydrogen peroxide $\left(\mathrm{H}_{2} \mathrm{O}_{2}\right)$. Elevated levels of iron have been found in postmortem sections of patients with Parkinson's disease (Hirsch et al., 1991; Sofic et al., 1991). Our data indicate that GDF-15/MIC-1 can protect against ironmediated cytotoxicity as efficiently as neurotrophin-4. This, together with the observation that GDF-15/MIC-1 is at least as potent as GDNF in promoting the survival of DAergic neurons makes this molecule attractive for assessing its potency in the treatment of human Parkinson's disease. The significance of GDF15/MIC-1 for promoting survival of midbrain DAergic neurons is further underscored by the fact that its neurotrophic effects are not 

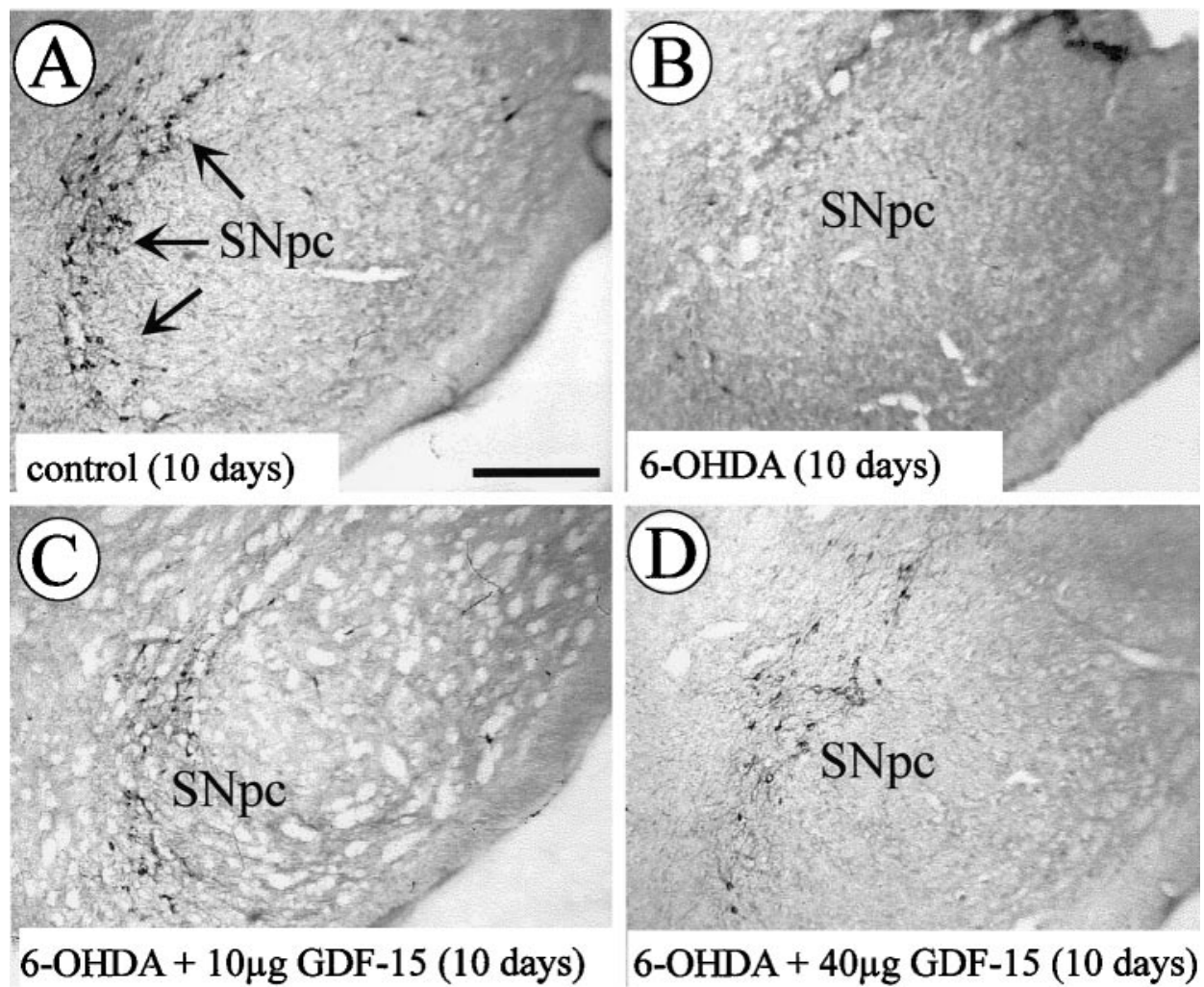

Figure 5. Photomicrographs of cryosections through the left SNpc. Sections were processed for TH immunocytochemistry. Animals were treated as follows: $A$, vehicle only; $B$, 6-OHDA only (10 d); $C$, 6-OHDA plus 10 $\mu \mathrm{g}$ of GDF-15/MIC-1 (10 d); D, 6-OHDA plus $40 \mu \mathrm{g}$ of GDF-15/MIC-1 (10 d); E, 6-OHDA only (1 month); $F$, 6-OHDA plus $40 \mu \mathrm{g}$ of GDF-15/MIC-1 (1 month). Scale bar, $200 \mu \mathrm{m}$.
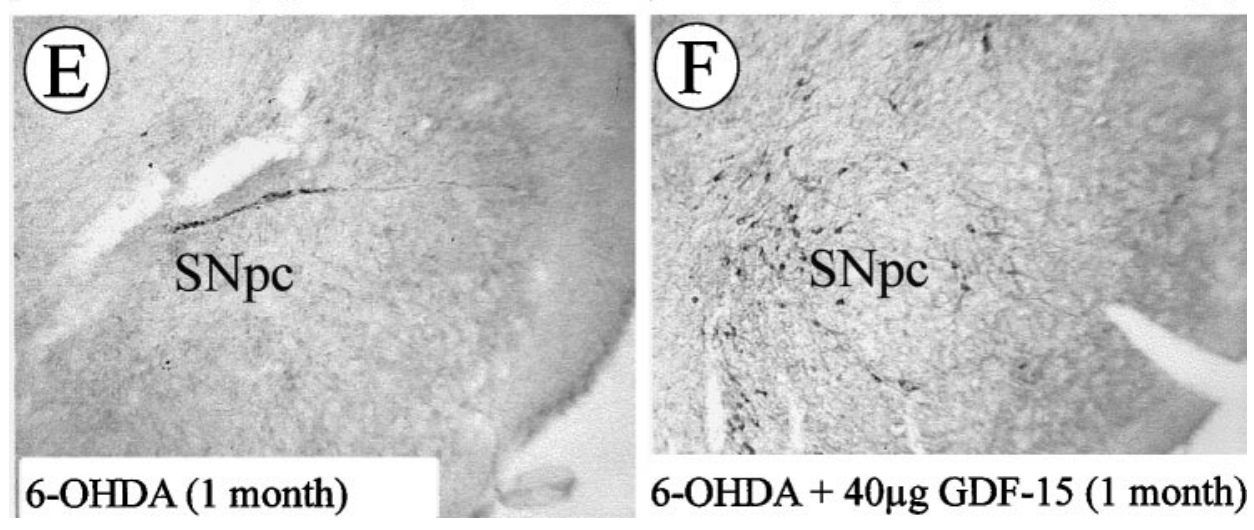

mediated by astroglial cells. Both control and treated cultures contained $<0.2 \%$ GFAP-positive cells (Hyman et al., 1991), and their numbers did not increase in response to GDF-15/MIC-1. In contrast, the dopaminotrophic effects of several growth factors including BMPs, FGF-2, EGF, TGF- $\alpha$, IGF-I, and IGF-II (Casper et al., 1991; Engele and Bohn, 1991; Alexi and Hefti, 1993; Jordan et al., 1997) are accompanied by a massive increase in cell number. Their effects are abolished by inhibition of cell proliferation and astroglial maturation arguing against a therapeutic potential of these factors.

Most importantly, GDF-15/MIC-1 effectively protects the adult rat nigrostriatal pathway against a complete lesion induced by 6-OHDA. GDF-15/MIC-1 preserved both striatal nerve terminals, as shown by the absence of amphetamine-induced rotational behavior, and dopaminergic cell bodies in the SNpc, as seen in the immunocytochemical study. It is promising that the neuroprotective effects of GDF-15/MIC-1 are still evident after 1 month. The neuroprotective effects of GDF-15/MIC-1 compare well with those previously observed with GDNF and GDF-5 in this rat model of Parkinson's disease (Sullivan et al., 1997, 1998). In the present study, a dose of $40 \mu \mathrm{g}$ of GDF-15/MIC-1 induced sparing of $67.7 \%$ of dopaminergic neurons after $10 \mathrm{~d}$ and of $62.0 \%$ after 1 month. Following the same administration protocol as that used in the present study, a total dose of $75 \mu \mathrm{g}$ of GDNF induced $77.5 \%$ survival of dopaminergic neurons, whereas $50 \mu \mathrm{g}$ of GDF-5 spared
$65.0 \%$. Because the failure of the recent clinical trial of GDNF in a Parkinsonian patient (Kordower et al., 1999), the search for effective dopaminergic neurotrophic factors remains. The present data suggest that GDF-15/MIC-1 may have the potential to be of therapeutic benefit in Parkinson's disease.

With regard to the spectrum of responsive neuron populations, the present data suggest that GDF-15/MIC-1 may preferentially address DAergic and serotonergic neurons, making it an interesting factor for potential applications in the treatment of Parkinson's disease and disorders of the serotonergic system. In terms of biological responses GDF-15/MIC-1 is distinct from GDNF, which addresses a wider spectrum of CNS and PNS neurons (Unsicker et al., 1999). With TGF- $\beta 1 / 2 / 3$, GDF-15/MIC- 1 shares CNS aminergic neurons as targets (Krieglstein et al., 1994, 1995a; Galter and Unsicker, 1999), but is distinct in that it does not address spinal cord motoneurons (Goudin et al., 1996; Krieglstein et al., 1998a).

In conclusion, the present data indicate that GDF-15/MIC-1, a novel member of the TGF- $\beta$ superfamily, is a potent neurotrophic factor for developing and lesioned aminergic neurons in vitro and in vivo, with a potency matching that of GDNF.

\section{REFERENCES}

Aebischer P, Schluep M, Delon N, Joseph JM, Hirt L, Heyd B, Goddard M, Hammang JP, Zurn AD, Kato AC, Regli F, Baetge EE (1996) Intra- 
thecal delivery of CNTF using encapsulated genetically modified xenogeneic cells in amyotrophic lateral sclerosis patients. Nat Med 2:696-699.

Alexi T, Hefti F (1993) Trophic actions of transforming growth factor alpha on mesencephalic neurons developing in culture. Neuroscience 55:903-918.

Behar T, McMorris FA, Novotny EA, Barker JL, Dubois-Dalc M (1988) Growth and differentiation properties of $\mathrm{O}-2 \mathrm{~A}$ progenitors purified from rat cerebral hemispheres. J Neurosci Res 21:168-180.

Bieger S, Unsicker K (1996) Functions of fibroblast growth factors (FGFs) in the nervous system. In: Chemical factors in neuronal growth, degeneration and repair (Bell C, ed), pp 339-361. Amsterdam: Elsevier.

Bootcov MR, Bauskin AR, Valenzuela SM, Moore AG, Bansal M, He XY, Zhang HP, Donnellan M, Mahler S, Pryor K, Walsh BJ, Nicholson RC, Fairlie WD, Por SP, Robbins JM, Breit SN (1997) Mic-1, a novel macrophage inhibitory cytokine, is a divergent member of the TGF- $\beta$ superfamily. Proc Natl Acad Sci USA 94:11514-11519.

Böttner M, Unsicker K, Suter-Crazzolara C (1998) Cloning and characterization of a new member of the TGF- $\beta$ superfamily. Eur J Neurosci [Suppl] 10:120.

Böttner M, Suter-Crazzolara C, Schober A, Unsicker K (1999) Expression of a novel member of the TGF- $\beta$ superfamily, growth/differentiation factor-15/macrophage inhibiting cytokine-1 (GDF-15/MIC-1) in adult rat tissues. Cell Tissue Res 297:103-110.

Böttner M, Krieglstein K, Unsicker K (2000) The TGF- $\beta$ s: structure, signalling roles in the nervous system development functions. J Neurochem 75:2227-2240.

Casper D, Mytilineou C, Blum M (1991) EGF enhances the survival of dopamine neurons in rat embryonic mesencephalon primary cell culture. J Neurosci Res 30:372-381.

Cohick WS, Clemmons DR (1993) The insulin-like growth factors. Annu Rev Physiol 55:131-153.

Constam DB, Schmid P, Aguzzi A, Schachner M, Fontana A (1994) Transient production of TGF- $\beta_{2}$ by postnatal cerebellar neurons and its effect on neuroblast proliferation. Eur J Neurosci 6:766-778.

Dixon CE, Flinn P, Bao J, Venya R, Hayes RL (1997) Nerve growth factor attenuates cholinergic deficits following traumatic brain injury in rats. Exp Neurol 146:479-490.

Engele J, Bohn MC (1991) The neurotrophic effects of fibroblast growth factors on neurons in vitro are mediated by mesencephalic glia. J Neurosci 11:3070-3078.

Finch CE, Laping NJ, Morgan TE, Nichols NR, Pasinetti GM (1993) TGF- $\beta 1$ is an organizer of responses to neurodegeneration. J Cell Biochem 53:314-322.

Flanders KC, Thompson NL, Cissel DS, Van Obberghen-Schilling E Bakker CC, Kass ME, Ellingsworth LR, Roberts AB, Sporn MB (1989) Transforming growth factor-beta 1: histochemical localization with antibodies to different epitopes. J Cell Biol 108:653-660.

Flanders KC, Ren GF, Lippa CF (1998) Transforming growth factor-betas in neurodegenerative disease. Prog Neurobiol 54:71-85.

Galter D, Unsicker K (1999) Regulation of the transmitter phenotype of rostral and caudal groups of cultured serotonergic raphe neurons. Neuroscience 87:549-560.

Gash DM, Zhang Z, Ovadia A, Cass WA, Yi A, Simmerman L, Russell D, Martin D, Lapchak PA, Collins F, Hoffer BJ, Gerhardt GA (1996) Functional recovery in Parkinsonian monkeys treated with GDNF. Nature 380:252-255.

Gerlach M, Riederer C (1996) Animal models of Parkinson's disease: an empirical comparison with the phenomenology of the disease in man. J Neural Transm 103:987-1041.

Goudin A, Bloch-Gallego E, Tanaka H, Rosenthal A, Henderson CE (1996) Transforming growth factor-beta 3, glial cell line-derived neurotrophic factor, and fibroblast growth factor-2, act in different manners to promote motoneuron survival in vitro. J Neurosci Res 43:454-464.

Henkel AW, Bieger SC (1994) Quantification of proteins dissolved in an electrophoresis sample buffer. Anal Biochem 223:329-331.

Hirsch EC, Brandel JP, Galle P, Javoy-Agid F, Agid Y (1991) Iron and aluminum increase in the substantia nigra of patients with Parkinson's disease: an X-ray microanalysis. J Neurochem 56:446-451.

Hogan BL (1996) Bone morphogenetic proteins: multifunctional regulators of vertebrate development. Genes Dev 10:1580-1594.

Huang CC, Chang YC, Chow NH, Wang ST (1997) Level of transforming growth factor beta 1 is elevated in cerebrospinal fluid of children with acute bacterial meningitis. J Neurol 244:634-638.

Hyman C, Hofer M, Barde YA, Juhasz M, Yancopoulos GD, Squinto SP, Lindsay RM (1991) BDNF is a neurotrophic factor for neurons of the substantia nigra. Nature 350:230-232.

Ishihara A, Saito H, Abe K (1994) Transforming growth factor-beta 1 and -beta 2 promote neurite sprouting and elongation of cultured rat hippocampal neurons. Brain Res 639:21-25.

Jaszai J, Farkas L, Galter D, Reuss B, Strelau J, Unsicker K, Krieglstein K (1998) The GDNF-related factor Persephin is widely distributed throughout the nervous system. J Neurosci Res 53:494-501.

Jordan J, Böttner M, Schluesener H, Unsicker K, Krieglstein K (1997) Bone morphogenetic proteins: neurotrophic roles for midbrain neurons and implications of astroglial cells. Eur J Neurosci 9:1699-1710.
Jung M, Kramer E, Grzenkowski M, Tang K, Blakemore W, Aguzzi A, Khazaie K, Chlichlia K, von Blankenfeld G, Kettenmann H, Trotter J (1995) Lines of murine oligodendroglial precursor cells immortalized by an activated neu tyrosine kinase show distinct degrees of interaction with axons in vitro and in vivo. Eur J Neurosci 7:1245-1265.

Kingsley DM (1994) The TGF- $\beta$ superfamily: new members, new receptors, and new genetic tests of function in different organisms. Genes Dev 8:133-146.

Kordower JH, Palfi S, Chen E-Y, Ma SY, Sendra T, Cochran EJ, Mufson EJ, Penn R, Goetz CG, Comella CD (1999) Clinicopathological findings following intraventricular glial-derived neurotrophic factor treatment in a patient with Parkinson's disease. Ann Neurol 46:419-424.

Krieglstein K, Unsicker K (1994) Transforming growth factor beta promotes survival of neurons of the substantia nigra. Neuroscience 63:1189-1196.

Krieglstein K, Rufer M, Suter-Crazzolara C, Unsicker K (1995a) Neural functions of the transforming growth factor- $\beta$. Int $\mathrm{J}$ Dev Neurosci 13:301-315.

Krieglstein K, Suter-Crazzolara C, Fischer WH, Unsicker K (1995b) TGF-beta superfamily members promote survival of midbrain neurons and protect them against MPP+ toxicity. EMBO J 14:736-742.

Krieglstein K, Henheik P, Farkas L, Jaszai J, Galter D, Krohn K, Unsicker K (1998a) Glial cell line-derived neurotrophic factor requires transforming growth factor- $\beta$ for exerting its full neurotrophic potential on peripheral and CNS neurons. J Neurosci 18:9822-9834.

Krieglstein K, Reuss B, Maysinger D, Unsicker K (1998b) Transforming growth factor- $\beta$ mediates the neurotrophic effect of fibroblast growth factor-2 on midbrain neurons. Eur J Neurosci 10:2746-2750.

Lin HY, Wang XF, Ng-Eaton E, Weinberg RA, Lodish HF (1992) Expression cloning of the TGF- $\beta$ type II receptor, a functional transmembrane serine/threonine kinase. Cell 68:775-785.

Lin LF, Doherty DH, Lile JD, Bektesh S, Collins F (1993) GDNF: a glial cell line-derived neurotrophic factor for midbrain neurons. Science 260:1130-1132.

Lingor P, Unsicker K, Krieglstein K (1999) GDF-5 protects midbrain neurons from radical damage. J Neural Transm 106:139-144.

Martinou J-C, le van Thai A, Valette A, Weber M J (1990) Transforming growth factor $b_{1}$ is a potent survival factor for rat embryo motoneurons in culture. Dev Brain Res 52:175-181.

McDonald NQ, Hendrickson WA (1993) A structural superfamily of growth factors containing a cystine knot motif. Cell 73:421-424.

McKinnon RD, Piras G, Ida Jr JA, Dubois-Dalcq M (1993) A role for TGF-beta in oligodendrocyte differentiation. J Cell Biol 121:1397-1407.

Mehler MF, Kessler JA (1998) Cytokines in brain development and function. Adv Prot Chem 52:223-251.

Pellegrino LJ, Pellegrino AS, Cushman AJ (1979) A stereotaxic atlas of the rat brain. New York: Plenum.

Reissmann E, Ernsberger U, Francis-West PH, Rueger D, Brickell PM, Rohrer H (1996) Involvement of bone morphogenetic protein-4 and bone morphogenetic protein-7 in the differentiation of the adrenergic phenotype in developing sympathetic neurons. Development 122:2079-2088.

Roberts AB, Sporn MB (1990) The transforming growth factors- $\beta$ s. In: Handbook of experimental pharmacology (Sporn MB, Roberts AB, eds), pp 419-472. Heidelberg: Springer.

Ruberg M, France-Lanord V, Brugg B, Lambeng N, Michel PP, Anglade P, Hunot S, Damier P, Faucheux B, Hirsch E, Agid Y (1997) Neuronal death caused by apoptosis in Parkinson disease. Rev Neurol (Paris) 153:499-508.

Sauer H, Rosenblad C, Björklund A (1995) GDNF but not TGF- $\beta 3$ prevents delayed degeneration of nigral neurons following striatal 6-hydroxydopamine lesion. Proc Natl Acad Sci USA 92:8935-8939.

Schober A, Hertel R, Arumae U, Farkas L, Jaszai J, Krieglstein K, Saarma M, Unsicker K (1999) Glial cell line-derived neurotrophic factor rescues target-deprived sympathetic spinal cord neurons but requires transforming growth factor-beta as cofactor in vivo. J Neurosci 19:2008-2015.

Scopes RK (1987) Protein purification: principles and practice, Ed 2. In: Springer advanced texts in chemistry (Cantor CR, ed), pp 1-323. New York: Springer.

Shah NM, Groves AK, Anderson DJ (1996) Alternative neural crest cell fates are instructively promoted by TGFbeta superfamily members. Cell 85:331-343.

Sofic E, Paulus W, Jellinger K, Riederer P, Youdim MB (1991) Selective increase of iron in substantia nigra zone compacta of Parkinsonian brains. J Neurochem 56:978-982.

Sullivan AM, Opacka-Juffry J, Hotten G, Pohl J, Blunt SB (1997) Growth/ differentiation factor 5 protects nigrostriatal dopaminergic neurones in a rat model of Parkinson's disease. Neurosci Lett 233:73-76.

Sullivan AM, Opacka-Juffry J, Blunt SB (1998) Long-term protection of the rat nigrostriatal dopaminergic system by glial cell line-derived neurotrophic factor against 6-hydroxydopamine in vivo. Eur J Neurosci 10:57-63.

Unsicker K, Suter-Crazzolara C, Krieglstein K (1999) Neurotrophic roles of GDNF and related factors. In: Handbook of experimental pharmacology 134: "Neurotrophic Factors" (Hefti F, ed), pp 189-224. Heidelberg: Springer. 